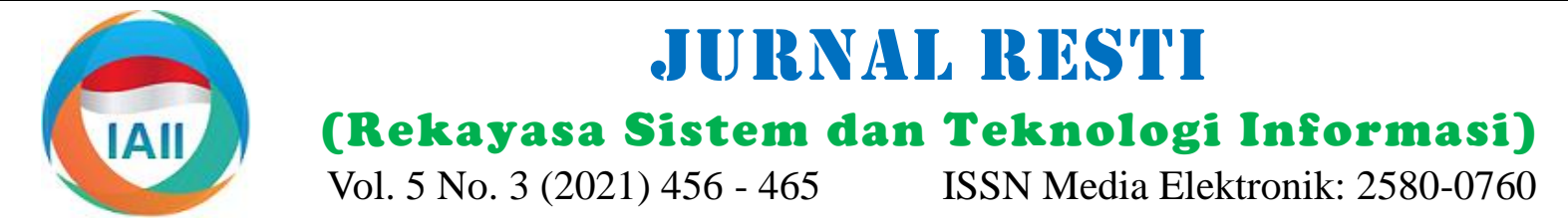

\title{
Prediksi Indeks BEI dengan Ensemble Convolutional Neural Network dan Long Short-Term Memory
}

\author{
Harya Widiputra $^{1}$, Adele Mailangkay ${ }^{2}$, Elliana Gautama ${ }^{3}$ \\ ${ }^{1}$ Fakultas Teknologi Informasi, Perbanas Institute \\ ${ }^{1}$ harya@ perbanas.id, ${ }^{2}$ adele@ perbanas.id, ${ }^{3}$ elliana@ perbanas.id
}

\begin{abstract}
The Indonesian Stock Exchange (IDX) stock market index is one of the main indicators commonly used as a reference for national economic conditions. The value of the stock market index is often being used by investment companies and individual investors to help making investment decisions. Therefore, the ability to predict the stock market index value is a critical need. In the fields of statistics and probability theory as well as machine learning, various methods have been developed to predict the value of the stock market index with a good accuracy. However, previous research results have found that no one method is superior to other methods. This study proposes an ensemble model based on deep learning architecture, namely Convolutional Neural Network (CNN) and Long Short-Term Memory (LSTM), called the CNN-LSTM. To be able to predict financial time series data, CNN-LSTM takes feature from CNN for extraction of important features from time series data, which are then integrated with LSTM feature that is reliable in processing time series data. Results of experiments on the proposed CNN-LSTM model confirm that the hybrid model effectively provides better predictive accuracy than the stand-alone time series data forecasting models, such as CNN and LSTM.
\end{abstract}

Keywords: BEI indexes, ensemble, Convolutional Neural Network, Long Short-Term Memory, deep learning, time series data.

\begin{abstract}
Abstrak
Indeks pasar saham Bursa Efek Indonesia (BEI) telah menjadi salah satu indikator utama yang umum digunakan sebagai referensi kondisi perekonomian nasional. Selain itu, nilai indeks pasar saham juga seringkali digunakan oleh perusahaan investasi maupun investor individual sebagai salah satu acuan dalam mengambil keputusan investasi. Oleh sebab itu, kemampuan untuk dapat memprediksi pergerakan nilai indeks pasar saham menjadi sebuah kebutuhan yang kritis. Dalam bidang ilmu statistika dan teori probabilitas maupun machine learning telah banyak dikembangkan berbagai metode untuk meramalkan nilai indeks pasar saham dengan tingkat akurasi yang baik. Namun demikian, berbagai hasil penelitian sebelumnya telah menemukan bahwa tidak ada satu metode yang paling unggul dibandingkan metode lainnya. Oleh sebab itu, penelitian ini mengusulkan sebuah model ensemble yang berbasis pada arsitektur deep learning yaitu Convolutional Neural Network $(C N N)$ dan Long Short-Term Memory (LSTM), yang disebut CNN-LSTM. Untuk dapat melakukan prediksi data deret waktu keuangan, $C N N-L S T M$ mengambil fitur unggulan dari $C N N$ untuk ekstraksi fitur penting dari data deret waktu, yang kemudian diinetgrasikan dengan fitur $L S T M$ yang handal dalam memproses data deret waktu. Hasil uji coba terhadap model CNN-LSTM yang dibangun mengkonfirmasi bahwa model hybrid secara efektif memberikan akurasi prediksi yang lebih baik dibandingkan dengan model peramalan data deret waktu yang berdiri sendiri, seperti halnya CNN dan LSTM.
\end{abstract}

Kata kunci: indeks BEI, ensemble, Convolutional Neural Network, Long Short-Term Memory, deep learning, data deret waktu.

\section{Pendahuluan}

Pergerakan indeks pasar saham selalu identik sebagai salah satu indikator penting dalam menilai kondisi perekonomian sebuah negara, sehingga menjadi sebuah masalah yang sangat penting di bidang ekonomi [1]. Secara umum, pergerakan indeks pasar saham dipengaruhi oleh berbagai faktor internal dan eksternal, Metode analisis tradisional untuk meramal arah seperti lingkungan ekonomi dalam dan luar negeri, pergerakan indeks pasar saham umumnya berbasis pada situasi internasional, prospek industri dan operasi pasar analisa ekonomi dan keuangan yang utamanya saham, namun utamanya sangat terpengaruh oleh nilai historis dari indeks pasar saham itu sendiri. Berdasarkan karakteristik tersebut, maka berbagai metode peramalan pergerakan indeks pasar saham juga memiliki titik fokus yang berbeda dibandingkan dengan metode peramalan data deret waktu lainnya $[2,3]$. 
menggunakan teknik analisis fundamental dan juga klasifikasi namun ternyata juga dapat memberikan hasil analisis teknis. Dalam hal ini, teknik analisis prediksi deret waktu yang baik. Selain itu, penelitian fundamental lebih memperhatikan nilai intrinsik saham- yang dipublikasikan oleh [6] juga mengkonfirmasi saham yang diperdagangkan di bursa efek dan secara kinerja model pembelajaran deep learning lainnya yang kualitatif menganalisis faktor-faktor eksternal yang lebih umum digunakan untuk prediksi data deret waktu, mempengaruhinya, seperti halnya suku bunga, nilai yaitu Long Short-Term Memory atau LSTM dalam tukar, inflasi, kebijakan industri, dan faktor ekonomi peramalan harga saham.

serta politik lainnya. Di sisi lain, teknik analisis teknikal fokus pada arah harga saham-saham yang diperdagangkan di bursa efek, volume perdagangan, dan ekspektasi psikologis investor. Teknik analisis teknikal juga fokus pada analisis lintasan historis dari indeks pasar guna menemukan pola-pola tertentu yang muncul secara berulang. Hingga saat ini, teknik analisis fundamental dan teknikal masih menjadi metode yang paling umum digunakan oleh banyak perusahaan investasi maupun dan investor individual dalam memperkirakan arah gerak indeks pasar saham untuk kemudian mengambil keputusan investasi [4,5].

Namun demikian, tingkat akurasi dari teknik analisis fundamental sulit untuk diyakini. Alasannya, faktorfaktor yang mempengaruhi tidak hanya dalam siklus jangka panjang, tetapi juga hasil prediksi yang lebih bergantung pada kualitas profesional analis atau bersifat subjektif. Indeks pasar saham masuk dalam kategori data deret waktu finansial, yang dalam hal ini memiliki karakteristik khusus, yaitu sifat random walk [6].

Dalam bidang ilmu statistika dan teori probabilitas, beberapa ahli menggunakan model peramalan deret waktu linier untuk memprediksi indeks pasar saham jangka pendek dengan sejumlah besar data jangka panjang, seperti vector autoregression (VAR) [7] Bayesian vector autoregression model (BVAR) [8], autoregressive integrated moving average mode (ARIMA) [9], dan generalized autoregressive conditional heteroskedasticity model (GARCH) [10], guna menangani data deret waktu dengan karakteristik random walk. Tetapi, tingkat akurasi peramalan yang dihasilkan oleh berbagai model deret waktu linier tersebut sering kali dipertanyakan. Hal ini karena tingginya tingkat ketidakpastian dan karakteristik derau yang tinggi dari data deret waktu keuangan serta terus terjadinya perubahan yang dinamis pada hubungan antara variabel independen dan variabel dependen-nya [11].

Selain beberapa model peramalan data deret waktu dari bidang ilmu statistika dan teori probabilitas di atas, dalam bidang ilmu machine learning khususnya jaringan saraf tiruan juga telah banyak dikembangkan banyak model pembelajaran deep learning untuk pemodelan dan prediksi data deret waktu [12]. Diantaranya adalah Convolutional Neural Network atau CNN yang Guna merealisasikan tujuan penelitian dan juga merupakan salah satu model pembelajaran deep menjawab rumusan masalah yang telah ditetapkan, learning yang telah digunakan pada beberapa penelitian maka tahapan-tahapan yang akan dilakukan dalam sebelumnya untuk melakukan prediksi data deret waktu penelitian ini dijabarkan pada Gambar 1. Adapun [12], dimana ditemukan bahwa meskipun pada tahapan penelitian sebagaimana diperlihatkan pada umumnya $C N N$ banyak digunakan untuk proses Gambar 1 dijelaskan lebih lanjut sebagai berikut.
Namun demikian, memprediksi arah pergerakan nilai deret waktu dengan hanya menggunakan sebuah model tunggal, baik yang berupa model peramalan deret waktu linier ataupun jaringan saraf tiruan, memiliki keterbatasan yang signifikan. Sehingga, menggabungkan berbagai algoritma terbaik untuk dapat memanfaatkan berbagai kelebihan yang dimiliki masing-masing algoritma dengan membangun sebuah model hybrid telah menjadi arah perkembangan dalam proses analisa dan pemodelan data deret waktu keuangan sekarang ini [12].

Sejalan dengan hal itu, model peramalan data deret waktu dalam penelitian ini dirancang dengan memanfaatkan karakteristik terbaik dari kedua model pembelajaran deep learning tersebut. Model hybrid atau menggabungkan keunggulan $C N N$, yang dapat mengekstraksi berbagai fitur-fitur penting dari data, dengan kekuatan LSTM yang tidak hanya dapat menemukan saling ketergantungan antar data dalam data deret waktu, tetapi juga secara otomatis mampu mendeteksi mode terbaik serta relevan untuk data deret waktu yang diproses sehingga secara efektif dapat meningkatkan akurasi peramalan nilai indeks pasar saham. Pada arsitektur CNN-LSTM yang diusulkan, layer $C N N$ digunakan untuk ekstraksi fitur dari data waktu masukan dan layer LSTM dimanfaatkan untuk memprediksi nilai penutupan dari indeks pasar saham pada hari berikutnya.

Untuk memverifikasi keefektifan model yang dirancang, penelitian ini menggunakan data pergerakan indeks pasar saham harian di Bursa Efek Indonesia, sejumlah 242 hari perdagangan dari 1 Januari 2020 hingga 31 Desember 2020.

\section{Metode Penelitian}

Penelitian yang dilaksanakan adalah penelitian perancangan atau yang dikenal sebagai Design Science Research [13]. Secara umum penelitian Design Science Research bertujuan untuk memecahkan masalah yang bersifat nyata dengan pendekatan membangun sebuah solusi baik dalam bentuk model, algoritma, perangkat lunak, proto-tipe ataupun kerangka kerja. ensemble yang dibangun dalam penelitian ini

DOI: https://doi.org/10.29207/resti.v5i3.3111

Creative Commons Attribution 4.0 International License (CC BY 4.0) 
Awareness of Problem, melakukan kajian model deret waktu dengan mengintegrasikan CNN dan LSTM, ensemble CNN-LSTM untuk diterapkan guna membantu atau membangun model ensemble yang disebut sebagai proses pemodelan dan prediksi pergerakan data deret CNN-LSTM. Dengan konsep ensemble ini diharapkan waktu.

solusi yang diberikan akan menjadi lebih baik serta

Suggestion, merancang struktur ensemble CNN-LSTM guna memodelkan dan melakukan prediksi pergerakan data deret waktu.

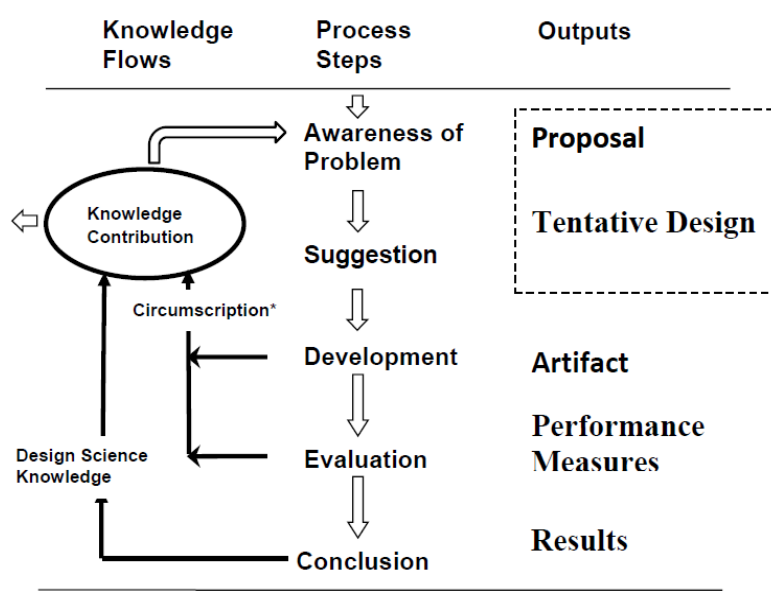

Gambar 1. Kerangka metode Design Science Research yang menjadi metodologi utama dalam pelaksanaan penelitian [13]

Development, implementasi struktur ensemble CNNLSTM dan pengumpulan data nyata untuk uji coba kinerja dalam pemodelan dan prediksi pergerakan data deret waktu.

Evaluation, uji coba dan evaluasi struktur ensemble CNN-LSTM yang dikembangkan menggunakan data nyata yang telah dikumpulkan. Pada tahap ini apabila ditemukan masalah, maka akan kembali pada tahap di mana $l_{t}$ mewakili nilai keluaran setelah proses perancangan serta implementasi untuk memperbaiki konvolusi, tanh adalah fungsi aktivasi yang umum kinerjanya. Dilanjutkan dengan evaluasi serta analisa digunakan, $x_{t}$ adalah vektor masukan, $k_{t}$ adalah nilai komparasi terhadap hasil uji coba dari CNN-LSTM bobot dari kernel konvolusi, $b_{t}$ dan merupakan bias dari dibandingkan dengan metode prediksi pergerakan data kernel konvolusi. Jika tidak menggunakan bias, berarti deret waktu lainnya.

Conclusion, penarikan kesimpulan yang akan Setelah operasi konvolusi yang terjadi pada layer memberikan kontribusi pada perkembangan domain konvolusi, fitur penting dari data diekstraksi yang ilmu, dalam hal ini analisa data deret waktu dan jaringan disertai dengan peningkatan dimensi fitur. Untuk saraf tiruan.

\subsection{Pengembangan Model CNN-LSTM}

CNN dan LSTM dapat dimanfaatkan untuk membangun model deep learning yang memiliki kemampuan mempelajari secara mendalam pola-pola yang bersifat kompleks dan tersembunyi dalam tumpukan data yang beragam dan berukuran masif, termasuk didalamnya adalah data deret waktu khususnya dari bidang keuangan.

Memberdayakan keunggulan yang dimiliki oleh kedua model tersebut, untuk mencapai tujuan dari penelitian ini sebagaimana telah disampaikan pada bagian Pendahuluan, yaitu guna meningkatkan akurasi peramalan pergerakan indeks pasar saham, maka dalam penelitian ini dibangun sebuah model peramalan data $b_{t}$ adalah 0 .

komprehensif karena tiap-tiap model memiliki peran dan kemampuan yang berbeda untuk dapat menangkap pola yang tersembunyi dalam data.

CNN adalah model jaringan yang diusulkan oleh Lecun dkk. pada tahun 1998 [14]. CNN adalah salah satu model feedforward neural network, yang memiliki kinerja yang baik dalam pemrosesan gambar dan juga natural language processing [15]. Meskipun pada umumnya $C N N$ lebih sering diaplikasi pada data citra, namun model ini juga telah terbukti dapat diterapkan secara efektif pada peramalan data deret waktu [16]

Karakteristik utama dari $C N N$ adalah kemampuan untuk dapat mengenali dan mengekstrak berbagai fitur yang tampak jelas dari garis pandang, sehingga model ini sangat umum digunakan dalam proses rekayasa fitur khususnya ekstraksi fitur dari data.

Salah satu keunggulan utama $C N N$ adalah fitur local perception dan weight sharing yang dapat sangat engurangi jumlah parameter, sehingga meningkatkan pada proses pembelajaran. Dari sisi struktur, Cerdiri dari dua bagian, yaitu layer (pooling). Dalam hal ini, setiap layer konvolusi berisi sejumlah kernel konvolusi, yang rumus

$l_{t}=\tanh \left(x_{t} * k_{t}+b_{t}\right)$ mengatasi masalah ini dan mengurangi beban pada proses pelatihan, maka lapisan penyatuan ditambahkan dengan tujuan utama melakukan reduksi kembali terhadap jumlah fitur yang diekstraksi.

Jaringan konvolusional $C N N$ diilhami oleh proses biologis $[17,18,19]$ karena pola konektivitas antara neuron menyerupai organisasi korteks visual hewan. CNN menggunakan pre-processing yang relatif lebih sedikit dibandingkan dengan algoritma klasifikasi gambar lainnya. Cara kerja $C N N$ diilustrasikan pada Gambar 2.

Di sisi lain, LSTM adalah sub-unit dari recurrent neural network (RNN). LSTM sangat cocok untuk mengklasifikasi, memproses, dan membuat prediksi berdasarkan data deret waktu tunggal. Pada 2016, 
perusahaan teknologi besar termasuk Google, Apple, serta kondisi sel kandidat pada input gate diperoleh dan Microsoft menggunakan LSTM sebagai komponen setelah kalkulasi menggunakan Rumus 3 dan 4.

fundamental dalam produk barunya. Sebagai contoh, Google menggunakan LSTM untuk pengenalan suara pada smartphone [20], untuk asisten pintar Allo [21] dan untuk Google Translate [22,23]. Sedangkan Apple menggunakan LSTM untuk fungsi Quicktype pada iPhone [24,25] dan untuk Siri.
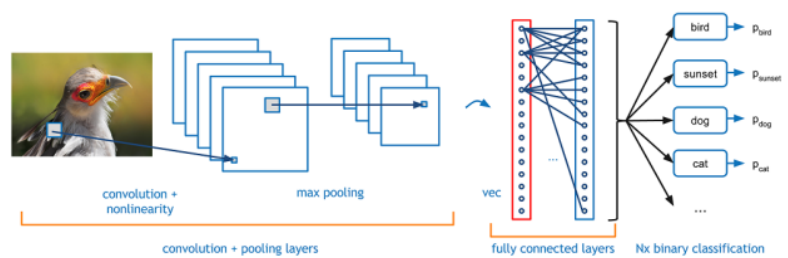

Gambar 2. Ilustrasi struktur $C N N$ yang umum digunakan dalam proses pengenalan citra [17]

$$
\begin{aligned}
& i_{t}=\sigma\left(W_{i} \cdot\left[h_{t-1}, x_{t}\right]+b_{i}\right), \\
& \widetilde{C}_{t}=\tanh \left(W_{c} \cdot\left[h_{t-1}, x_{t}\right]+b_{c}\right),
\end{aligned}
$$

dimana rentang nilai dari $i_{t}$ adalah $(0,1), W_{i}$ adalah bobot dari input gate, $b_{i}$ adalah nilai bias dari input gate, $W_{c}$ adalah bobot dari kandidat input gate, dan $b_{c}$ adalah nilai bias dari kandidat input gate.

Tahap berikutnya pada model LSTM adalah proses penyesuaian nilai sel atau parameter model pada saat ini dilakukan berdasarkan Rumus 5.

$$
C_{t}=f_{t} * C_{t-1}+i_{t} * \widetilde{C}_{t},
$$

dimana rentang nilai dari $C_{t}$ adalah $(0,1)$. Kemudian, pada pemrosesan waktu $t$, nilai keluaran $h_{t-1}$ dan nilai Selain itu, dalam beberapa tahun terakhir ini LSTM juga masukan $x_{t}$ menjadi masukan untuk output gate, dan telah diadopsi di bidang peramalam pergerakan nilai di keluaran dari output gate dihitung menggunakan Rumus pasar saham [26,27,28], dimana struktur internal LSTM 6.

yang dibangun cukup sederhana dan hanya menggunakan satu modul backpropagation seperti halnya dalam struktur $R N N$ biasa. Adapun, sel memori LSTM terdiri dari tiga bagian, yaitu: forget gate, input bobot , rang gate, dan output gate sebagaimana yang ditunjukkan output gate. pada Gambar 3 .

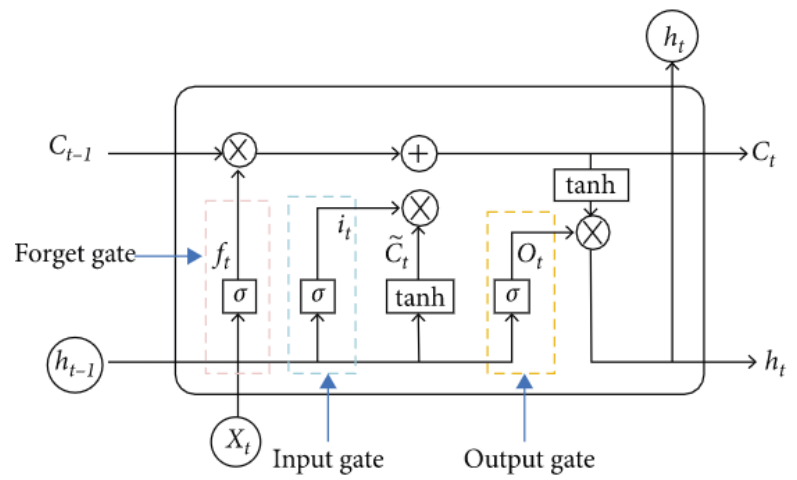

Gambar 3. Struktur standar model LSTM yang terdiri dari komponen forget gate, input gate dan output gate dengan fitur backpropagation [29]

Proses komputasi yang terjadi dalam struktur LSTM guna melakukan penghitungan prediksi data deret waktu diawali dengan penghitungan nilai keluaran dari waktu sebelumnya dan nilai masukan dari waktu saat ini menjadi masukan ke forget gate, dan hasil pemrosesan dari forget gate diperoleh melalui komputasi menggunakan Rumus 2.

$$
f_{t}=\sigma\left(W_{f} \cdot\left[h_{t-1}, x_{t}\right]+b_{f}\right),
$$

dimana rentang nilai dari $f_{t}$ adalah $(0,1), W_{f}$ adalah bobot dari forget gate, dan $b_{f}$ adalah nilai bias yang diterapkan pada forget gate, $x_{t}$ adalah nilai masukan untuk waktu saat ini, dan $h_{t-1}$ adalah nilai keluaran dari pemrosesan waktu sebelumnya. Selanjutnya, nilai keluaran dari waktu sebelumnya dan nilai masukan dari waktu saat ini juga menjadi masukan ke input gate, dan nilai keluaran

$$
o_{t}=\sigma\left(W_{0}\left[h_{t-1}, x_{t}\right]+b_{o}\right) \text {, }
$$

Pada akhirnya, nilai keluaran akhir dari LSTM dihasilkan oleh output gate dan merupakan hasil kalkulasi menggunakan Rumus 7.

$$
h_{t}=o_{t} * \tanh \left(C_{t}\right) \text {. }
$$

dalam hal ini tanh adalah fungsi aktivasi yang dapat disesuaikan dengan kebutuhan maupun karakteristik dari permasalahan yang akan diselesaikan.

LSTM memiliki kemampuan untuk memproses data yang direkam secara urutan waktu tertentu, dan oleh karenanya telah digunakan secara luas dalam proses analisa dan pemodelan data deret waktu.

Struktur dari model ensemble CNN dan LSTM yang dibangun pada penelitian ini mengacu pada struktur yang digunakan oleh Lu, dkk. pada penelitian mereka yang memprediksi pergerakan harga saham di bursa efek Shanghai [29]. Namun demikian, struktur data masukan, konfigurasi parameter pada tiap layer dan juga parameter proses pelatihan dalam penelitian ini disesuaikan dengan karakteristik data indeks pasar saham BEI.

Diagram struktur dari model CNN-LSTM diperlihatkan pada Gambar 4, dimana CNN dan LSTM menjadi komponen utama disertai dengan layer masukan (input), layer konvolusi 1 dimensi (1D convolutional), layer penyatuan (pooling), layer tersembunyi LSTM (hidden), dan layer koneksi penuh (full connection) yang akan mengeluarkan hasil akhir prediksi. 


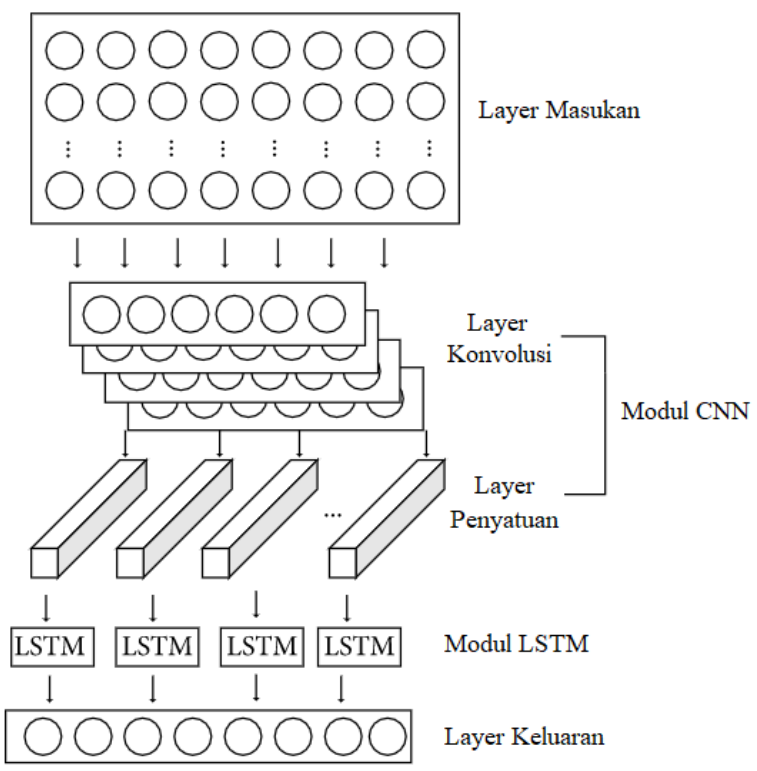

Gambar 4. Diagram struktur model CNN-LSTM untuk prediksi nilai data deret waktu [29]

\subsection{Proses Pelatihan dan Prediksi CNN-LSTM}

Tahapan proses pelatihan dan prediksi CNN-LSTM pada data deret waktu ditampilkan pada Gambar 5. Secara rinci tahapan pelatihan dimulai dengan proses input data latih (training), pada tahap ini terjadi proses memasukan data yang digunakan untuk pelatihan CNN-LSTM. Tahap selanjutnya adalah inisialisasi parameter jaringan guna menetapkan bobot dan nilai bias (jika ada) pada awal Jika berdasarkan hasil evaluasi ditetapkan kondisi setiap layer CNN-LSTM. Kemudian, dilanjutkan dengan berhenti untuk pelatihan belum dicapai, maka nilai proses pada layer $C N N$ dimana data masukan secara kesalahan yang dihitung dipropagasi kembali ke layer berurutan melewati layer konvolusi dan layer penyatuan sebelumnya dan kemudian dilakuan penyesuaian bobot (pooling) pada layer CNN, dilanjutkan dengan proses serta nilai bias pada tiap layer (error backpropagation), ekstraksi fitur data masukan, serta menghasilkan nilai dan proses pelatihan Kembali dilakukan hingga kondisi keluaran yang akan menjadi masukan untuk layer berhenti tercapai. Namun jika salah satu syarat dari LSTM. Pada layer CNN ini utamanya terjadi proses kondisi berhenti untuk pelatihan terpenuhi, maka ekstraksi fitur dari data deret waktu yang menjadi pelatihan selesai dan konfigurasi seluruh jaringan $C N N$ masukan bagi layer LSTM.

LSTM disimpan.

Selanjutnya nilai keluaran dari layer CNN akan Tahap selanjutnya adalah pengujian model CNN-LSTM memasuki layer LSTM. Pada layer LSTM ini utamanya yang telah selesai dilatih menggunakan data uji. Proses terjadi proses prediksi nilai deret waktu yang diamati, ini dimulai dengan memasukan data uji yang digunakan dimana nilai keluaran dari layer LSTM menjadi masukan untuk prediksi atau input data uji (testing) ke model untuk layer koneksi penuh (full connection) yang CNN-LSTM yang telah disimpan untuk kemudian kemudian menghasilkan nilai akhir prediksi. Pada tahap mendapatkan nilai keluaran (hasil prediksi) sebagai ini proses pelatihan prediksi selesai dan kemudian keluaran akhir dari proses pelatihan dan prediksi $C N N$ dilanjutkan dengan proses evaluasi hasil pelatihan LSTM.

dimana dilakukan penghitungan kesalahan hasil prediksi. Nilai keluaran berupa hasil prediksi yang dihitung oleh layer keluaran dibandingkan dengan nilai sebenarnya dari kelompok data yang diproses, untuk kemudian dihitung nilai kesalahannya.

Hasil evaluasi menjadi acuan untuk menentukan apakah

Pengukuran tingkat akurasi akan dilakukan dengan menerapkan penghitungan nilai Root Mean Square Error (RMSE), guna melihat besaran simpangan antara nilai sebenarnya terhadap nilai prediksi yang dihasilkan.

\subsection{Implementasi Model CNN-LSTM}

kondisi berhenti untuk pelatihan terpenuhi. Dalam hal Sebagaimana telah dijelaskan sebelumnya struktur ini, kondisi berhenti pelatihan adalah tercapainya jumlah model CNN-LSTM yang dibangun terdiri dari 2 (dua) siklus pelatihan yang telah ditentukan (epochs), dan nilai layer komponen utama, yaitu layer CNN dan layer LSTM. Adapun, layer CNN terdiri dari: layer konvolusi

DOI: https://doi.org/10.29207/resti.v5i3.3111

Creative Commons Attribution 4.0 International License (CC BY 4.0) 
1 dimensi, layer penyatuan (pooling), dan layer perataan sebagai kriteria utama metode evaluasi. Adapun nilai (flatten). Sedangkan layer LSTM terdiri dari: layer RMSE dihitung menggunakan Rumus 8. tersembunyi LSTM (hidden), dan layer pemadatan (dense). Pada penelitian ini konfigurasi dari parameter CNN-LSTM menggunakan Keras di Python diberikan pada Tabel 1, dimana jumlah kernel diset 1 karena prediksi bersifat univariate atau hanya melibatkan 1 variabel masukan, dan struktur rinci dari model $C N N$ LSTM diilustrasikan pada Gambar 6.

Tabel 1. Konfigurasi parameter pada tiap layer struktur CNN-LSTM yang diusulkan untuk prediksi nilai indeks pasar saham BEI. Konfigurasi parameter mengacu pada konfigurasi yang digunakan oleh [29] dan [30] pada penelitiannya mengenai pemanfaatan CNNLSTM untuk prediksi data deret waktu

\begin{tabular}{lcc}
\hline \multicolumn{1}{c}{ Parameter } & Nilai & Layer \\
\hline Filter layer konvolusi & 64 & $C N N$ \\
Jumlah kernel pada filter & 1 & $C N N$ \\
Fungsi aktivasi layer konvolusi & Relu & $C N N$ \\
Padding layer penyatuan & Valid & CNN \\
Pool_size layer penyatuan & 2 & $C N N$ \\
Jumlah hidden unit pada layer LSTM & 50 & LSTM \\
Fungsi aktivasi layer LSTM & Relu & LSTM \\
Time step & 4 & LSTM \\
Optimizer & Adam & LSTM \\
Loss function & MAE & LSTM \\
Epochs & 500 & Model Fit \\
\hline
\end{tabular}

\subsection{Data, Alat Penelitian dan Evaluasi}

Data lapangan yang digunakan dalam hal ini adalah data harian pergerakan indeks pasar saham atau indeks harga saham gabungan Bursa Efek Indonesia (BEI). Data dapat diunduh dari Yahoo Finance pada tautan https://finance.yahoo.com/lookup. Jangka waktu pengumpulan data adalah pada periode 1 Januari 2020 s.d. 31 Desember 2020 atau selama periode pandemi Covid-19 dimana pergerakan indeks pasar saham menjadi lebih tidak pasti.

Selanjutnya, alat dukung yang digunakan dalam penelitian ini adalah komputer untuk melakukan perancangan dan implementasi struktur CNN-LSTM serta uji coba dan evaluasi kinerja dari model peremalan data deret waktu yang dibuat. Dalam hal ini, komputer juga digunakan untuk melakukan implementasi struktur menggunakan lingkungan pemrograman Python 2.7 dan library Keras.

Sebagaimana telah disampaikan pada bagian Pendahuluan, tujuan utama dari penelitian ini adalah untuk dapat membangun sebuah struktur jaringan saraf tiruan yang dapat mempelajari pola gerak data deret waktu dan memprediksi nilainya di waktu mendatang sert dan menguji kinerja dari model tersebut khususnya untuk memprediksi pergerakan nilai indeks BEI. Oleh sebab itu, analisa hasil yang dilakukan pada penelitian ini akan fokus pada tingkat akurasi dari stuktur $C N N$ LSTM dalam memprediksi pergerakan nilai indeks pasar saham BEI.

Selanjutnya, untuk melakukan evaluasi kinerja dari CNN-LSTM dalam memprediksi pergerakan indeks pasar saham, dalam penelitian ini digunakan nilai $R M S E$

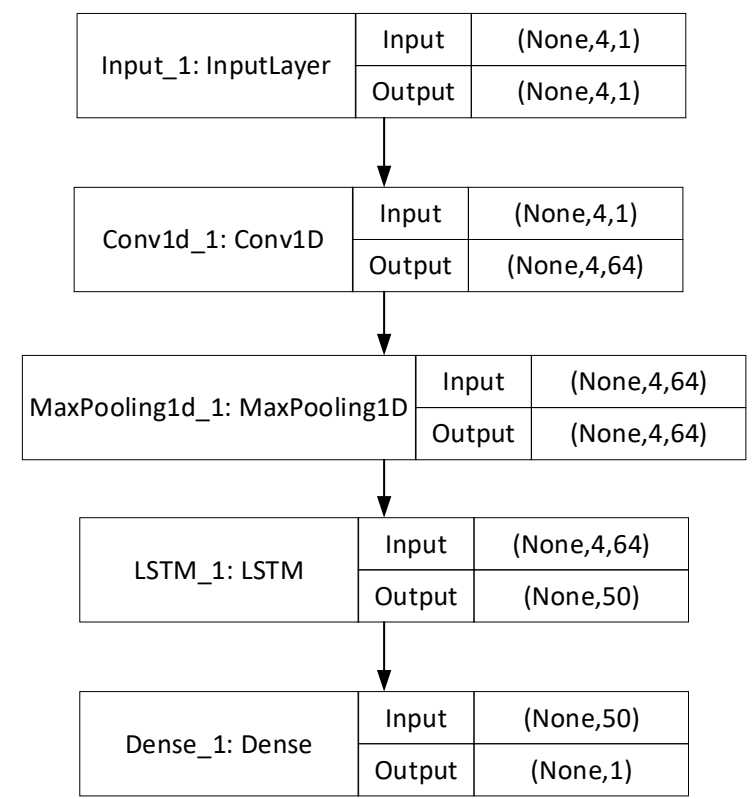

Gambar 6. Struktur rinci model CNN-LSTM yang diusulkan disertai dengan perubahan dimensi data input dan output pada tiap layer-nya

$R M S E=\sqrt{\frac{1}{n} \sum_{i=1}^{n}\left(\widehat{y}_{l}-y_{i}\right)^{2}}$

dimana $\widehat{y}_{l}$ adalah hasil prediksi untuk indeks pasar saham pada waktu $i$ dan $y_{i}$ adalah nilai nyata atau sebenarnya dari indeks pasar saham pada waktu $i$.

\section{Hasil dan Pembahasan}

\subsection{Analisa Grafik Perbandingan Hasil Prediksi}

Sebagaimana telah disampaikan implementasi model CNN-LSTM yang dibangun dalam penelitian ini dilakukan menggunakan lingkungan pemrograman Python 2.7 dan library Keras. Modul utama yang dibuat terdiri dari modul pembangunan model CNN-LSTM, modul prediksi, dan modul penghitungan nilai error untuk evaluasi kinerja model CNN-LSTM dalam memprediksi nilai indeks pasar saham BEI.

Implementasi dari modul pembangunan model $C N N$ LSTM diberikan sebagai berikut:

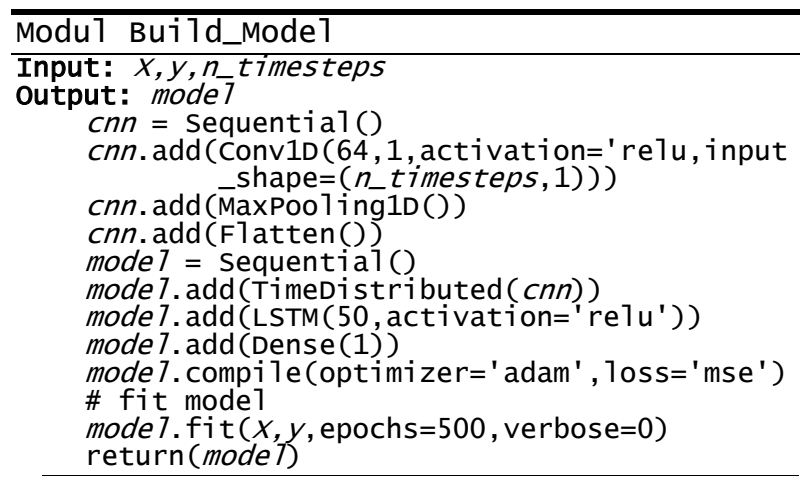


Masukan pada modul Build_Model adalah $X$, yaitu Evaluasi kinerja terhadap model CNN-LSTM yang kumpulan data yang akan menjadi masukan prediksi; $y$, dibangun dilakukan menggunakan data uji setelah yaitu target nilai prediksi; dan $n \_t i m e s t e p s$ yaitu jumlah model $C N N$-LSTM dilatih menggunakan data latih. langkah data ke belakang yang digunakan untuk Adapun data latih yang digunakan adalah sejumlah 170 memprediksi data pada waktu berikutnya dan sampel data harian nilai indeks pasar saham BEI yang menghasilkan keluaran berupa model CNN-LSTM yang merupakan 70\% bagian dari keseluruhan 242 data harian telah dilatih. Selanjutnya, implementasi untuk modul nilai indeks pasar saham pada periode 1 Januari 2020 prediksi diberikan sebagai berikut:

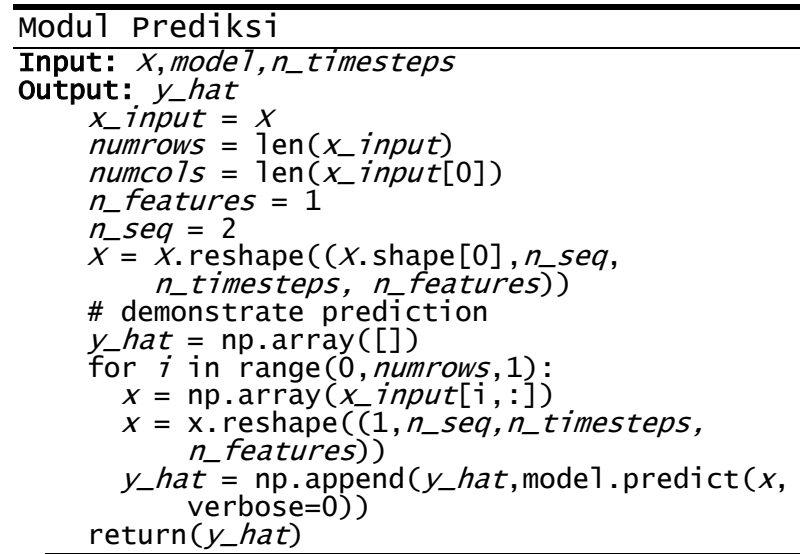

Pada modul Prediksi, masukannya adalah $X$, yaitu kumpulan data yang akan menjadi masukan proses prediksi; n_timesteps yaitu jumlah langkah data ke belakang yang digunakan untuk memprediksi data pada waktu berikutnya; dan juga model, yaitu model $C N N$ LSTM yang telah dilatih. Keluaran dari model ini adalah y_hat, yaitu hasil prediksi. Kemudian, implementasi modul penghitungan kesalahan pada tiap titik waktu dan juga $R M S E$ diberikan sebagai berikut:

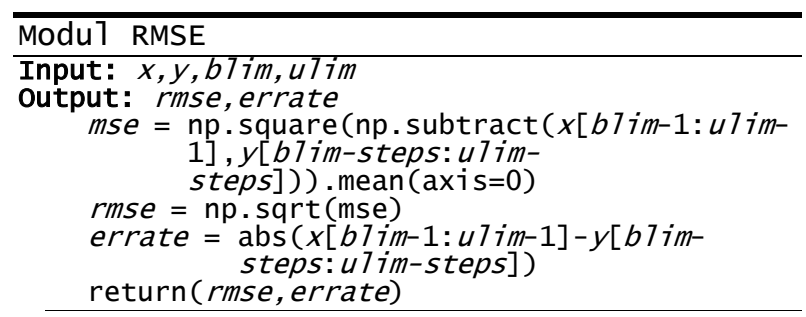

Pada modul RMSE, yang menjadi masukan adalah $x$, yaitu nilai asli dari indeks yang diprediksi; $y$, nilai hasil prediksi; blim adalah batas bawah data deret waktu yang diproses; dan ulim adalah batas atas data yang diproses. Keluaran dari modul ini adalah nilai RMSE dan nilai kesalahan prediksi pada tiap titik waktu (errate).

Perbandingan hasil prediksi pada tahap pelatihan dan juga tahap uji ditampilkan pada Gambar 7 dan 8 baik untuk model $C N N$ dan $L S T M$ secara individu dan juga model ensemble CNN-LSTM yang diusulkan dalam penelitian ini. Gambar 7 menampilkan grafik perbandingan antara nilai indeks pasar saham BEI hasil prediksi terhadap nilai aslinya pada tahap pelatihan, dan Gambar 8 menampilkan grafik perbandingan antara nilai indeks pasar saham BEI hasil prediksi terhadap nilai aslinya pada tahap pengujian. s.d. 31 Desember 2020, dan sisanya digunakan sebagai data uji. Data harian nilai indeks pasar saham BEI tersebut diunduh dari Yahoo Finance pada tautan https://finance.yahoo.com/lookup.

Secara umum dapat dilihat bahwa grafik nilai indeks pasar saham BEI yang merupakan hasil prediksi dari CNN-LSTM memiliki pola gerak yang mirip dan hampir berdempetan dengan laju grafik nilai indeks pasar saham BEI yang asli. Hal ini terjadi baik pada grafik perbandingan pada tahap pelatihan maupun pengujian. Fakta ini memberikan gambaran yang jelas bahwa model CNN-LSTM dengan konfigurasi parameter yang dibuat pada penelitian ini terbukti efektif untuk memprediksi nilai harian indeks pasar saham BEI.

Gambar 7 dan 8 juga menampilkan informasi mengenai error rate hasil prediksi, yang dihitung berdasarkan nilai mutlak dari selisih hasil prediksi dan nilai aslinya pada tiap titik waktu baik pada tahap pelatihan maupun pengujian. Grafik error rate juga mengindikasikan bahwa rata-rata error rate hasil prediksi berada pada kisaran yang dan relatif kecil dan dapat diterima.

Selain itu, mengingat bahwa data deret waktu yang diproses berada pada cakupan periode pandemi Covid19, dimana pergerakan berbagai indikator ekonomi menjadi lebih tidak pasti, model CNN-LSTM juga terkonfirmasi tetap memiliki kemampuan untuk memprediksi nilai dari data deret waktu keuangan dengan kinerja yang baik. Selisih terbesar antara prediksi dengan nilai asli terjadi pada kisaran hari perdagangan ke-55, yang jika dipetakan ke hari kalender jatuh pada awal Maret 2020 dimana pandemi Covid-19 mulai mempengaruhi kondisi perekonomian nasional. Namun setelah itu, tampak bahwa nilai error rate terus menurun yang mana mengindikasikan kemampuan model CNN-LSTM untuk beradaptasi dengan perubahan pola gerak nilai indeks pasar saham.

\subsection{Analisa RMSE}

Sebagaimana telah disampaikan sebelumnya, dalam penelitian ini kinerja dari model CNN-LSTM juga dievaluasi dengan melakukan penghitungan nilai $R M S E$. Penghitungan RMSE dilakukan baik pada tahap pelatihan dan juga pada tahap pengujian. Selain itu, untuk membuktikan bahwa membangun sebuah struktur ensemble CNN-LSTM yang merupakan integrasi dari model CNN dan LSTM, pada penelitian ini juga dilakukan uji coba prediksi nilai indeks pasar saham BEI dengan jumlah data dan konfigurasi data latih serta data uji yang sama menggunakan model $C N N$ dan model LSTM yang berdiri sendiri-sendiri. Perbandingan nilai

DOI: https://doi.org/10.29207/resti.v5i3.3111 
RMSE untuk masing-masing model dan tiap tahapannya diberikan pada Tabel 2 dan diilustrasikan pada Gambar 9.
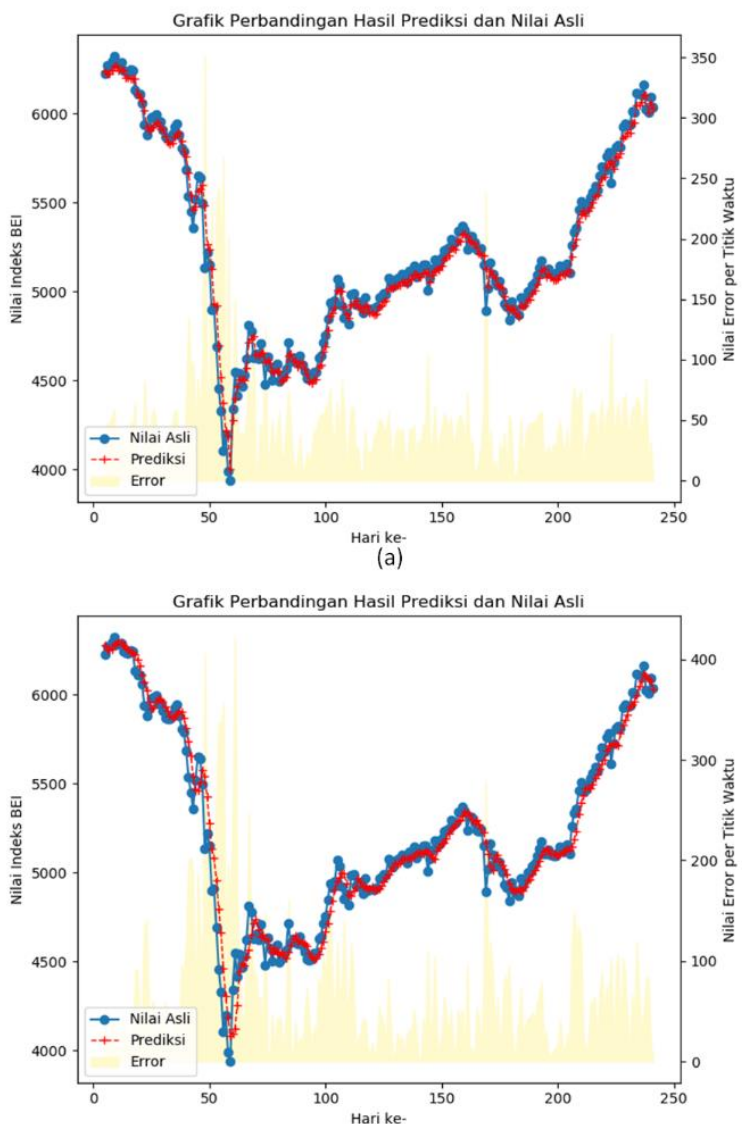

(b)

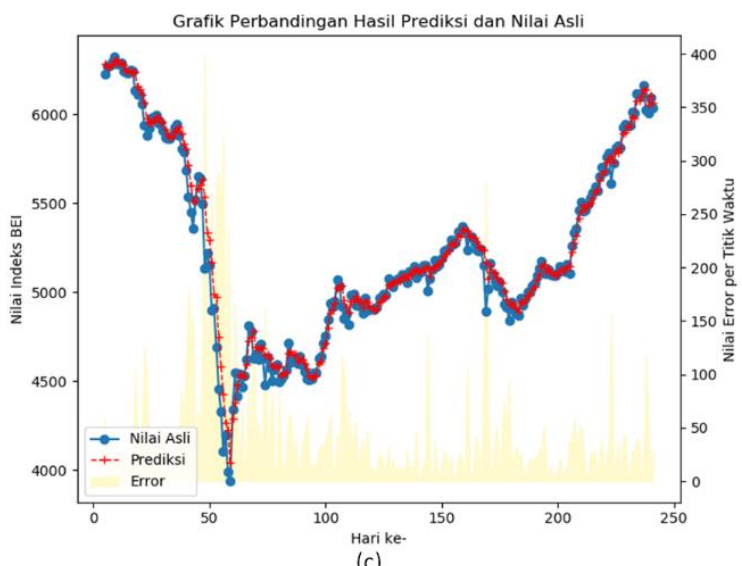

Gambar 7. Perbandingan hasil prediksi terhadap nilai asli indeks pasar saham pada periode pelatihan (170 hari pertama pada periode 1 Januari 2020 s.d. 31 Desember 2020), (a) pada model $C N N$, (b) pada model LSTM dan (c) pada model CNN-LSTM.

Tabel 2. Perbandingan nilai RMSE pada model CNN, LSTM dan $C N N-L S T M$ pada prediksi indeks pasar saham BEI

\begin{tabular}{lcc}
\hline \multirow{2}{*}{ Model } & \multicolumn{2}{c}{ RMSE } \\
\cline { 2 - 3 } & Pelatihan & Pengujian \\
\hline CNN & 121.07 & 125.74 \\
LSTM & 120.31 & 124.53 \\
CNN-LSTM & 112.47 & 117.59 \\
\hline
\end{tabular}
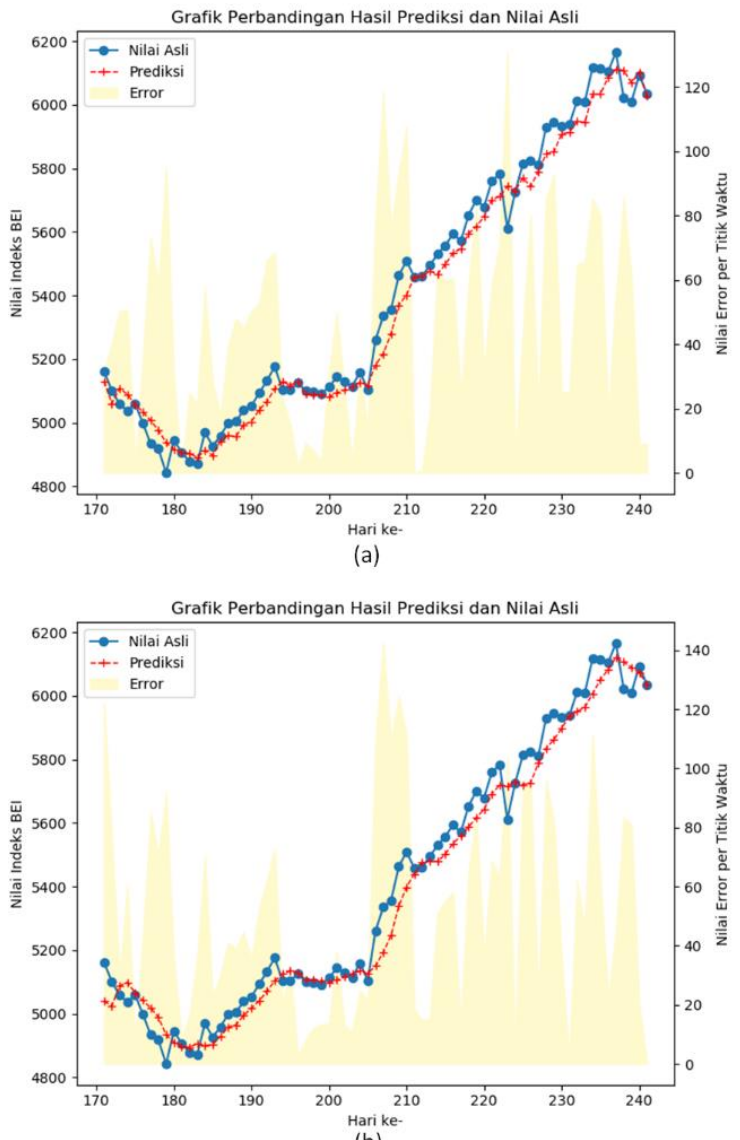

(b)

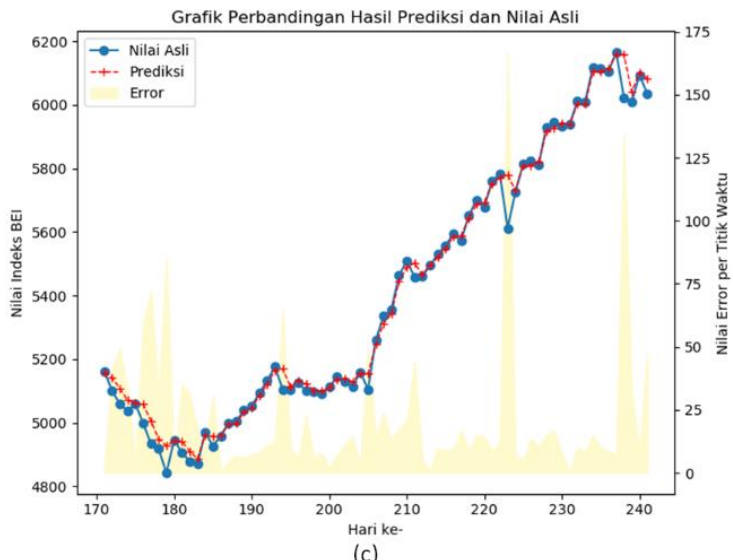

Gambar 8. Perbandingan hasil prediksi terhadap nilai asli indeks pasar saham pada periode pengujian (72 hari terakhir pada periode 1 Januari 2020 s.d. 31 Desember 2020), (a) pada model $C N N$, (b) pada model LSTM dan (c) pada model CNN-LSTM.

Berdasarkan nilai RMSE yang ditampilkan pada Tabel 2, maka dapat diambil kesimpulan bahwa akurasi terbaik diberikan oleh model $C N N-L S T M$, dengan peningkatan akurasi pada model CNN-LSTM sebesar $7.6 \%(C N N)$ dan $8.7 \%$ (LSTM) pada tahap training serta $2.7 \%$ (CNN) dan $1.6 \%$ (LSTM) pada tahap testing. Dengan demikian, fakta ini mengkonfirmasi teori yang menyatakan bahwa dengan menggabungkan berbagai fitur serta keunggulan yang dimiliki oleh model atau algoritma yang berbeda menjadi sebuah ensemble dapat memberikan hasil yang

DOI: https://doi.org/10.29207/resti.v5i3.3111 
lebih baik dalam penyelesaian sebuah masalah, yang Daftar Rujukan

dalam hal ini adalah untuk memprediksi nilai indeks pasar saham BEI.

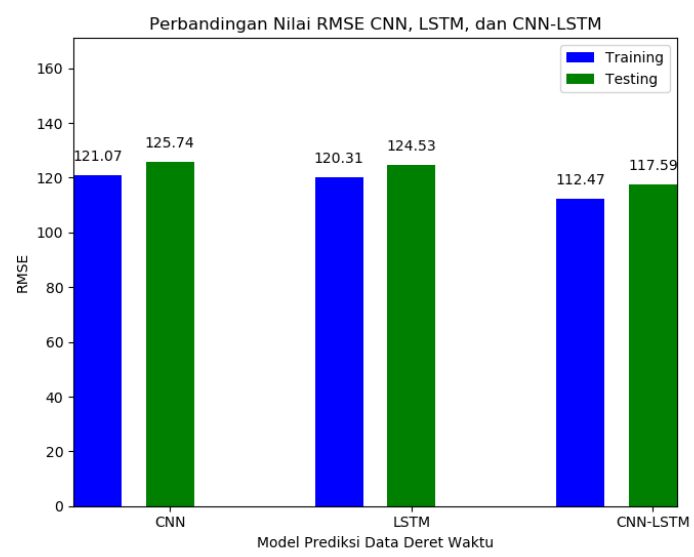

Gambar 9. Grafik perbandingan nilai RMSE model CNN, LSTM dan $C N N-L S T M$ pada periode pelatihan dan pegujian prediksi nilai indeks pasar saham BEI

\section{Kesimpulan}

Penelitian ini mengusulkan sebuah model CNN-LSTM untuk memprediksi nilai indeks pasar saham satu tahapan waktu ke depan (keesokan harinya). Metode yang digunakan adalah peramalan data deret waktu variabel tunggal (univariate), dimana prediksi indeks pasar saham dilakukan dengan hanya mempelajari pola gerak indeks itu sendiri pada masa yang lampau. Pada model yang dibangun, $C N N$ digunakan untuk ekstraksi fitur dari data masukan sedangkan LSTM memiliki peran untuk mempelajari data fitur yang diekstraksi serta melakukan proses akhir prediksi nilai indeks pasar saham keesokan harinya. Dalam uji coba digunakan data yang relevan dari Bursa Efek Indonesia sebagai data latih dan data uji untuk memverifikasi hasil eksperimen. Hasil percobaan menunjukkan bahwa CNN-LSTM memiliki akurasi prediksi tertinggi dan kinerja terbaik (memiliki nilai $R M S E$ terkecil) dibandingkan dengan model CNN dan LSTM secara individu.

Dengan demikian, dapat disimpulkan bahwa $C N N$ LSTM efektif untuk peramalan nilai indeks pasar saham dan dapat memberikan referensi yang relevan bagi investor untuk mengambil keputusan investasinya. Selain itu, CNN-LSTM juga memberikan alternatif praktis bagi penelitian yang berhubungan dengan pengembangan model untuk analisa data deret waktu keuangan.

\section{Ucapan Terimakasih}

Tim peneliti mengucapkan terima kasih kepada Direktorat Riset dan Pengabdian Masyarakat, Kemristek/BRIN Republik Indonesia atas pembiayaan yang diberikan melaui skema Hibah Penelitian Dasar tahun anggaran 2021.
[1] R. Vanaga and B. Sloka, "Financial and capital market commission financing: aspects and challenges," Journal of Logistics, Informatics and Service Science, vol. 7, no. 1, pp. 17$30,2020$.

[2] L. Zhang and H. Kim, "The influence of financial service characteristics on use intention through customer satisfaction with mobile fintech," Journal of System and Management Sciences, vol. 10, no. 2, pp. 82-94, 2020.

[3] L. Badea, V. Ionescu, and A.-A. Guzun, "What is the causal relationship between stoxx europe 600 sectors? But between large firms and small firms?" Economic Computation And Economic Cybernetics Studies And Research, vol. 53, no. 3, pp. $5-20,2019$.

[4] J. Sousa, J. Montevechi, and R. Miranda, "Economic lot-size using machine learning, parallelism, metaheuristic and simulation," Journal of Logistics, Informatics and Service Science, vol. 18, no. 2, pp. 205-216, 2019.

[5] A. Coser, M. M. Maer-Matei, and C. Albu, "Predictive models for loan default risk assessment," Economic Computation And Economic Cybernetics Studies And Research, vol. 53, no. 2, pp. 149-165, 2019.

[6] R. Qiao, "Stock prediction model based on neural network," Operations Research and Management Science, vol. 28, no. 10, pp. 132-140, 2019.

[7] C. Jung and R. Boyd, "Forecasting UK stock prices," Applied Financial Economics, vol. 6, no. 3, pp. 279-286, 1996.

[8] W. Bleesser and P. Liicoff, "Predicting stock returns with bayesian vector autoregressive," Data Analysis, Machine Learning and Applications, vol. 1, pp. 499-506, 2005.

[9] A. Adebiyi, A. Adewumi, and C. Ayo, "Stock price prediction using the ARIMA model," in Proceedings of the 2014 UKSimAMSS 16th International Conference on Computer Modelling and Simulation, IEEE, Cambridge, UK, March 2014.

[10] C. Zhang, X. Cheng, and M. Wang, "An empirical research in the stock market of Shanghai by GARCH model," Operations Research and Management Science, vol. 4, pp. 144-146, 2005.

[11] Q. Yang and C. Wang, "A study on forecast of global stock indices based on deep LSTM neural network," Statistical Research, vol. 36, no. 6, pp. 65-77, 2019.

[12] K.-S. Moon and H. Kim, "Performance of deep learning in prediction of stock market volatility," Economic Computation And Economic Cybernetics Studies And Research, vol. 53, no. 2, pp. 77-92, 2019.

[13] B. Kuechler, V. Vaishnavi, "Design Science Research in Information Systems," 2004.

[14] Y. Lecun, L. Bottou, Y. Bengio, and P. Haffner, "Gradientbased learning applied to document recognition," Proceedings of the IEEE, vol. 86, no. 11, pp. 2278-2324, 1998.

[15] B. S. Kim and T. G. Kim, "Cooperation of simulation and data model for performance analysis of complex systems," International Journal of Simulation Modelling, vol. 18, no. 4, pp. 608-619, 2019.

[16] Y. Sun, Y. Liang, and W. Zhang, "Optimal partition algorithm of the RBF neural network and its application to financial time series forecasting," Neural Computing and Applications, vol. 14, pp. 1441-1449, 2005.

[17] D. Ciresan, U. Meier, and J. Schmidhuber, "Multi-column deep neural networks for image classification," 2012 IEEE Conference on Computer Vision and Pattern Recognition, pp. 3642-3649, 2012.

[18] M.L. Brocardo, I. Traore, I. Woungang, and M.S. Obaidat, "Authorship verification using deep belief network systems," Int J Commun Syst., pp. 1013-1021, 2017.

[19] D. Silver, A. Huang, C. Maddison, A. Guez, L. Sifre, G. Driessche, J. Schrittwieser, I. Antonoglou, and V. Panneershelvam, "Mastering the game of Go with deep neural networks and tree search," Nature, vol. 529 , no. 7587, pp. 484489, 2016.

[20] A. Marblestone, G. Wayne, and K. Kording, "Toward an Integration of Deep Learning and Neuroscience," Frontiers in Computational Neuroscience, vol. 21, no. 3, pp. 213-230, 2016.

DOI: https://doi.org/10.29207/resti.v5i3.3111 
[21] Y. Bengio, A. Courville, and P. Vincent, "Representation [27] Learning: A Review and New Perspectives," IEEE Transactions on Pattern Analysis and Machine Intelligence, vol. 35, no. 8, pp. 1798-1828, 2013.

[22] L. Deng, and D. Yu, "Deep Learning: Methods and [28] Applications," Foundations and Trends in Signal Processing, vol. 7, no. 3-4, pp. 1-199, 2014.

[23] Y. Bengio, "Learning Deep Architectures for AI," Foundations and Trends in Machine Learning, vol. 2, no. 1, pp. 1-127, 2009.

[24] Y. LeCun, Y. Bengio, and G. Hinton, "Deep Learning," Nature, vol. 521, no. 7553, pp. 436-444, 2015.

[25] J. Schmidhuber, "Deep Learning in Neural Networks: An Overview," Neural Networks, vol. 61, pp, 85-117, 2015.

[26] A. Yadav, C. K. Jha, and A. Sharan, "Optimizing LSTM for time series prediction in Indian stock market," Procedia Computer Science, vol. 167, pp. 2091-2100, 2020.
27] H. Y. Kim and C. H. Won, "Forecasting the volatility of stock price index: a hybrid model integrating LSTM with multiple GARCH-type models," Expert Systems with Applications, vol. 103, pp. 25-37, 2018.

[28] N. C. Petersen, R. Christoffer, F. Rodrigues, and F. C. Pereira, "Multi-output bus travel time prediction with convolutional LSTM neural network," Expert Systems with Applications, vol. 120, pp. 426-435, 2019.

[29] W. Lu, J. Li, Y. Li, A. Sun, and J. Wang, "A CNN-LSTM-Based Model to Forecast Stock Prices," Complexity, https://doi.org/10.1155/2020/6622927, 2020.

[30] J. Brownlee, "Deep Learning for Time Series Forecasting Predict the Future with MLPs, CNNs and LSTMs in Python," Edition v.1.7, Machine Learning Mastery, San Juan, PR 00901, 2020. 